and has punctured the illusions held by some ${ }^{67}$ that the Webb law gave export associations a blanket exemption from the Sherman Act. Above all, however, the Alkasso case suggests the possibility that the exemption granted by the Webb Act may prove to be meaningless if the Act's provisos are properly enforced.

\title{
TEMPORAL ASPECTS OF THE FINALITY OF JUDGMENTS THE SIGNIFICANCE OF FEDERAL RULE 60(b)
}

A prime function of legal systems is the settling of controversies. Settling implies ending, and ending implies finality. Ordinarily, then, when final judgment is entered in a cause, all that remains is execution, the transmuting of law into force.

But there is yet another prime function of law, and that is to do justice between parties. Judgment settles controversies; but the settlement may not necessarily be the most just. Common-sense notions of justice would seem to require that decisions be changed when they do not correspond with prevalent notions of right.

The law has gradually been évolving techniques to allow the victims of incorrect "final" judgments to secure relief in court. The process has been long and slow. The desire for absolute finality is strong, and satisfies both aesthetic and administrative needs. Techniques of appeal and rehearing allow correction of lower court misapplication of law. The development of techniques for working substantial justice has been more difficult in cases where defects of fact rather than of law exist in the judgment, and the time for appeal or rehearing has passed.

At common law a judgment could be set aside during the same term of

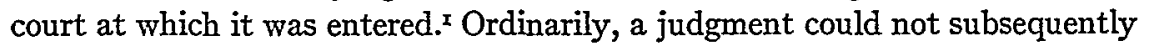
be set aside. Certain types of writs were available to set aside judgments after term, but these were not clearly defined, were cumbersome, and made no pretense of covering all the deserving cases. The two chief writs of this type were the writs of audita querela and coram nobis. Audita querela ${ }^{2}$ lay chiefly for

${ }^{67}$ See note 4 supra. Fortune Magazine also referred to Judge Kaufman's decision as introducing a " 'new' Webb Act." Fortune, Dec. I949, p. I86.

I I Hen. IV, c. 3 (I409): "The records and process of pleas real and personal ... on which judgment was entered and enrolled ... shall not be in any manner amended or impaired ... in any term after such judgment . . . was entered and enrolled." Co. Litt. *260(a): "Yet during the term wherein any judicial act is done, the record remaineth in the breast of the judges of the court, and in their remembrance, and, therefore, the roll is alterable during that term, as the judges shall direct; but when the term is past, then the record is in the roll, and admitteth of no alteration, averment, or proof to the contrary." See also Wooden \& Elizabeth's case, I

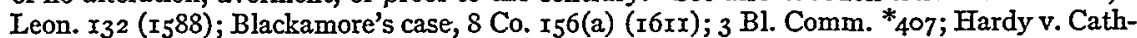
cart, I Marsh C. P. I80, I83 (I8I4); Waldo v. Spencer, 4 Conn. $7 I^{\circ}$ (I82I); Richardson v. Hunt, 7 R.I. 543 ( 1863 ).

2 The writ is of considerable antiquity. "Briefs de audita querela" are spoken of in the Mirror of Justices (Bk. 5, C. I, $\$ \mathrm{I}_{4}$ O) which was written in the late thirteenth century. On 
fraud on the part of the movent's adversary, or where "matter in discharge" had arisen since the time of judgment. Coram nobis ${ }^{3}$ (or coram vobis) 4 was used to obtain relief in cases of error of fact material to the validity of the judgment, and which had not been put into issue- the infancy or coverture of the defendant, for example. Audita querela was obsolete by Blackstone's time, having been driven out of use by the "indulgence of the courts in granting summary relief on motion." 5 The writ is available, at least theoretically, in a few American jurisdictions, ${ }^{6}$ but is almost as rare as trial by ordeal. Coram nobis is extensively used in a few states, ${ }^{7}$ but in the rest it is only a memory.

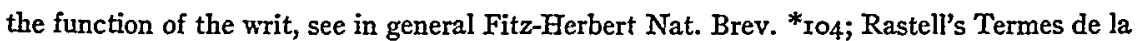
Ley $6_{3}$ (r708); 3 Bl. Comm. *405-6; Bac. Abr. Tit. Audita Querela; Stone v. Seaver, 5 Vt. 549 (1833).

3 This writ apparently branched off from the ordinary writ of error and became distinct. See Fitz-Herbert Nat. Brev. *20; Dyer ${ }^{2} 95$ (156r); Co. Litt. *259(b); Odell v. Moreton, Cro. Jac. 254 (16ro); Strode v. The Staffordshire Justices, I Brock. I62, Fed. Cas. No. 13,537 (1810). For the modern usage of coram nobis see Orfield, The Writ of Error Coram Nobis in Civil Cases, 20 Va. L. Rev. 423 (1934); I Freeman on Judgments $§ 257$ (5th ed. 1925); I Black on Judgments $\$ 299$ (I8gr).

- The distinction between coram nobis and coram vobis is purely historical. It is based on whether the writ is directed to the court of King's Bench or Common Pleas. Tidd's Practice II36; Devereux v. Roper, I Phila. Rep. 64 (Pa., I851).

Another ancient writ the effect of which was to upset a prior judgment was the writ of attaint. In Blackstone's description, this lay "to inquire whether a jury of twelve men gave a false verdict; that so the judgment following thereupon may be reversed; and this must be brought in the lifetime of him for whom the verdict was given; and of two at least of the jurors who gave it." $3 \mathrm{Bl}$. Comm. * $402-403$; see also Fitz-Herbert Nat. Brev. * ${ }^{\text {I05. }}$

The writ is of great antiquity. It was first used in the thirteenth century. I Holdsworth History of English Law 162; Bracton *292 ff.; Britton *237-246; Mirror of Justices, Bk. 3, c. 33-34. For an even older method of upsetting judgments, cf. Glanville, Bk. 8, c. g. The use of the writ of attaint was at first very narrow, but it was extended by statute to cover a wider variety of cases than fell within the compass of the original writ. 3 Edw. I, c. 38 (I275); I Edw. III, c. 6 (I327); 5 Edw. III, c. 7 (I33I); 28 Edw. III, c. 8 (r354); 34 Edw. III, c. 7

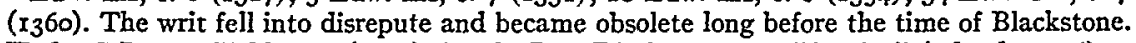
Hyde, C.J., at I Keble 864 (I664); Jacobs Law Dictionary, art. "Attaint" (7th ed., r756); 3 Bl. Comm. *404 ("I have observed few instances of an attaint in our books, later than the sixteenth century").

Blackstone also speaks of "the writ of deceit, or action on the case in the nature of it," which could be brought "in the court of common pleas, to reverse a judgment there had by fraud or collusion in a real action, whereby lands and tenements have been recovered to the prejudice of him that hath right." 3 Bl. Comm. *405; see also Fitz-Herbert Nat. Brev. *95 ("writ of disceit").

${ }^{5} 3$ Bl. Comm. *406; Bingham Law and Practice of Judgments and Executions 264 n. (e) (1815).

6 Fla. Comp. Gen. Laws Ann. (Skillman, I94I) c. 52, $\$ 20 ;$ Me. Rev. Stat. (I944) c. II4, $\$ \S$ I-7; Mass. Ann. Laws (I944) c. 249, § I; Vt. Pub. Laws (1947), \$§ 2148, 2154; Di Paola v. Seppala, 336 Ill. App. 344,83 N.E. 2 d 889 (r949); Robertson v. Commonwealth, 279 Ky. 762, 132 S.W. $2 d 69$ (1939).

7 See Orfield, The Writ of Error Coram Nobis in Civil Cases, 20 Va. X. Rev. 423 (I934). In some jurisdictions the writ was abolished but the substance was retained. Ill. Ann. Stat. (Smith-Hurd, 1948) c. 110, § 196: "The writ of error coram nobis is hereby abolished, and all errors in fact ... which by the common law could have been corrected by said writ may be 
Despite these quaint exceptions, and even assuming that some sort of time limit is necessary, the term rule is clearly inequitable. Judgments taken toward the end of the term are more "stable" than judgments taken at the beginning of the term. This inequity is most evident in cases where the judgment has been entered on the last day of the term and the motion to vacate filed on the first day of the next term. The common reaction of a court to such a situation is to grant the motion by any readily available means. ${ }^{8}$

Thus it does not surprise us that in most American jurisdictions the term rule has been tampered with, either by judicial evolution, ${ }^{9}$ or by statute. The result of these statutes is to impose a uniform time period, measured from the date the judgment was obtained, during which judgments may be upset irrespective of the expiration of the judicial term. In Illinois and several other states a thirty-day limit has been set up in place of the term..$^{10}$ In Kentucky there is a sixty-day limit. ${ }^{\mathrm{II}}$ In other states limits of six months, ${ }^{\mathrm{I2}}$ one year, ${ }^{\mathrm{x} 3}$

corrected by the court in which the error was committed upon motion in writing, made at any time within 5 years after the rendition of final judgment in the case. ..."

In the federal courts coram nobis and coram vobis became obsolete procedurally very early, and were supplanted by motion, which would be granted only if the case fell under the old common-law categories. Pickett v. Legerwood, 7 Pet. (U.S.) I44, 147 (I833).

${ }^{8}$ See Salus v. Fogel, 302 Pa. 268, I53 Atl. 547 (I93r); Kantor v. Herd, 276 Pa. 5I9, I20 Atl. $45^{\circ}$ (r923).

9 "A trial court has control over its judgments during the term at which they are rendered and afterwards, and possesses inherent power, for sufficient reasons, to order a final judgment vacated ... but whether this power shall be exercised in any given instance rests solely in the sound discretion of the court." Horicon v. Langlois' Estate, II5 Vt. 8x, 52 A. 2 d 888 (I947). See St. Pierre v. Beauregard, I03 Vt. 258, 152 Atl. $91_{4}$ (193 $\mathrm{r}$ ); Mutual Life Ins. Co. v. Foster, 88 Vt. 503, 93 Atl. 258 (I9I5); Farmer's Mutual Fire Ins. Co. v. Reynolds, 52 Vt. 405 (r880); Mosseaux v. Brigham, I9 Vt. 457 (I847); Adams v. Howard, I4 Vt. I58 (x842); Scott v. Stewart 5 Vt. 57 ( 1833 ). Needless to say, the vast majority of the courts of the country are unaware of this "inherent" power which the Vermont court has discovered in itself.

ro Ala. Code (I940) §§ r3-Ir4, I3-rrg; Pate v. State, 244 Ala. 396, I4 So. 2d 25 (I943); Ill. Ann. Stat. (Smith-Hurd, r948) c. IIO, $\$$ I74; Barnard v. Michael, 392 Ill. 130, 63 N.E. $2 d$ 858 (I945); Illinois Nat. Bank of Springfield v. Gwinn, 390 Ill. 345, 6r N.E. 2d 249 (I943); Broadway Motor Co. v. Public Fire Ins. Co., I2 Tenn. App. 278 (I930); Durham Coal Co. v. Bischel, 4 Tenn. App. 233 (I927); Gammel's Ann. Rules of Civ. Proc. in Texas, Rule 330 (r948); Joy v. Young, I94 S.W. 2 d I59 (Tex. Civ. App., r946).

In Maryland "the period of thirty days has been substituted in the law courts of Baltimore city," though elsewhere in the jurisdiction the term rule is in force. North v. Town Real Estate Corp., 60 A. 2d 665 (Md., r948); Armour Fertilizer Works v. Brown, I85 Md. 273, 44 A. 2d 753 (r945); Harvey v. Slacum, I8r Md. 206, 29 A. 2d 276 (I942).

Ir Ky. Rev. Stat. (I943) $\$ 45$ r.I30. This applies only to courts of "continuous session," that is, courts with no fixed term. See Hutchinson v. Hutchinson, 293 Ky. 270, x68 S.W. 2d 738 (1943); Stratton \& Terstegge Co. v. Begley, 249 Ky. 632, 6r S.W. 2 d 287 (1933).

I2 Ariz. Code Ann. (r939) § 2I-I502; Cal. Civ. Code (Deering, r949) §473; Colo. Code of Civ. Proc. (r94r) Rule 6o(b); Idaho Code Ann. (r947) $\$ 5$-905; Mont. Rev. Code Ann. (r949) $\S$ 93-3905; Nev. Comp. Laws ( 1929 ) § 8640; R.I. Gen. Laws (1938) c. 535, § 2; Utah Rev. Stat. (I933) \& I04-r4-4.

${ }^{23}$ Ark. Civ. Code Ann. (Crawford, I947) § 29-506; Iowa Code (1946) §§ 683, 683.I; Mich. Stat. Ann. (Henderson, I938) § 27.I433; Minn. Stat. (Mason, 1945) §544.32; N.C. Gen. Stat. (Michie, I943) § I-220; N.D. Rev. Code (1944) § 28-290I; Ohio Code Ann. (Throck- 
two years, ${ }^{14}$ and even three years ${ }^{15}$ have been established. Typically, ground for relief is "mistake, inadvertence, or surprise"; some statutes include fraud as a ground..$^{16}$ In Louisiana a more stringent rule than the term rule is in force, since judgments are ordinarily unimpeachable after the passage of three judicial days. ${ }^{17}$ Of course, when the time limit set up by statute is shorter than the duration of the term, uniformity has been achieved at the expense of litigants who obtain their judgments in the early part of the term. In the remaining states the term rule is the law. Few states, however, proclaim the rule in its pure form; most jurisdictions which still retain it have riddled it with exceptions. ${ }^{88}$

morton, I948) $\S \S$ rI63r, II640; Ore. Comp. Laws Ann. (I940) $\S$ r-1007; S.C. Code of Laws (I942) § 495; Wash. Rev. Stat. Ann. (Remington, 1932 ) $\$ \$ 464,466$; Wisc. Stat. (Brossard, r935) $\S 269.46$. The amended Federal Rule of Civil Procedure $6 \circ(\mathrm{b})$ has been adopted in New Mexico. N. Mex. Stat. Ann. (Supp. I949) § I9-Ior.

${ }^{2}$ Ind. Stat. Ann. (Burns, 1933) § 2-2603; Kan. Gen. Stat. (Corrick, 1936) $\$ \S 60-3007$, 60-3008; Neb. Rev. Stat. (I948) $\$ \S 25-2001,25-2008$; N.Y. Civ. Prac. Ann. (Cahill, 1937) $\$ \S 522,523,528$; Okla. Stat. Ann. (1942) §§ I2-103I, I038; Wyo. Rev. Stat. Ann. (Courtright, r946) §§ 3-380r, 3-38ro.

${ }^{15}$ Minn. Stat. (Mason, I946) $\S 548.14$ (fraud only). By statute in Georgia, Ga. Code (1933) $\$ 595^{8}$, "[T] such judgment was obtained, while a motion to set it aside may be made at any time within the statute of limitations." However, the grounds for such a motion are very limited. See Miraglia v. Bryson, I82 Ga. 828, III S.E. 655 (1922), and Frazier v. Beasley, 59 Ga. App. 500, I S.E. 2d $45^{8}$ (r939).

In Connecticut the term rule is officially in force, Clover Farms v. Kielwasser, ${ }_{34}$ Conn. 622,59 A. 2 d 550 (I948); Clark v. The Connecticut Co., $x_{32}$ Conn. 400, 402, 44 A. 2 d 706 (I945), but the "new trial" statute of Connecticut accomplishes the same purpose as the vacation statutes of other states. A new trial may be granted for "mispleading, the discovery of new evidence, or want of actual notice of the suit to any defendant ... . or for other reasonable cause according to the usual rules in such cases...," and the petition for new trial shall be brought "within three years next after the rendition of the judgment or decree complained of. ..." Conn. Rev. Stat. (r949) $\$ \S 8013,8322$.

${ }^{16}$ The statutes of Arkansas, Iowa, Kansas, Minnesota, Ohio, Washington, and Wyoming, for example.

${ }^{77}$ La. Civ. Code Ann. (Dart., r945) arts. 558, 560, 563.3; Albritton v. Nauls, ${ }_{5}$ So. $2 \mathrm{~d}$ I26 (La. App., I943); Jefferson v. Lauri N. Truck Line, I8r So. 821 (La. App., r938), aff'd I87 So. 44, I92 La. 29 (r939); see Flory \& McMahon, The New Federal Rules and Louisiana Practice, I La. L. Rev. 45, 75 ( $x_{938)}$.

In Massachusetts, according to recent authority, judgments are "ordinarily unimpeachable" as soon as rendered. Amory v. Kelley, $3^{\circ}$ Mass. 162, 34 N.E. 2d $5 \circ 7$ (I94I); Barnes v. Smith, IO4 Mass. 363 ( 1780 ). But there are all sorts of exceptions, including writ of error, on which there is a six-year time limit. Mass. Ann. Laws (Michie, 1933) c. 250, $\$ \S$ I-I5; I6 Mass. L. Q. 227 (193x).

${ }^{8}$ In Delaware, the term rule is in force, Szymanski v. Buchanan, 58 A. 2d 428, 430 (Del., I947), Tweed v. Lockton, 5 W. W. Harr. (Del.) 474, I67 Atl. 703 (I932), but "where it has appeared from the record . . . that the defendants have been deprived of rights given them by law, judgments have been vacated" after the term. Webb Packing Co. v. Harmon, 8 W. W. Harr. (Del.) 476, r93 Atl. 596 ( 1937 ). For a less vague enumeration of the exceptions to the term rule in Delaware, see Smulski v. H. Feinberg Furniture Co., 8 W. W. Harr. (Del.) 45x, 193 Atl. 585 (1937).

In Florida, a motion to vacate after term may be considered "if there was fraud, collusion, deceit, or mistake in the procuring of the judgment." Zemurray v. Kilgore, r3o Fla. 317, I77 
The most radical and carefully planned development in this field has taken place in the federal courts. The evolution since 1938 under the Federal Rules of Civil Procedure is indicative of the changing trends in this field.

Prior to the adoption, in 1938 , of the Federal Rules of Civil Procedure, the term rule held sway in the federal courts. ${ }^{x}$ By the adoption of Rule $60(\mathrm{~b})$, a "reasonable time" criterion was adopted in place of the term rule, but this

So. 7x4, 718 (I937); State v. Wright, Io7 Fla. 178, I45 So. 598 (I932); Alabama Hotel Co. v. Mott Iron Works, 86 Fla. 608, 98 So. 825 (I923); but see State v. Williams, I47 Fla. 5I4, 3 So. 2 d $15^{2}$ (I94I).

In Mississippi, "where the court has jurisdiction of the subject matter and the parties and renders judgment, it is without power to set aside such judgment after the term of court has elapsed." Strain v. Gayden, 197 Miss. 353, 20 So. 2d 697 (1945); Ex parte Stanfield, 89 Miss. 2x4, 53 So. 538 (igro).

In Missouri the term rule is in force, except that a motion in the nature of a writ of error coram nobis may be brought after the term has ended. City of St. Louis v. Franklin Bank, 35 I Mo. 688, I73 S.W. 2 d 837 (1943); Smith v. Smith, 350 Mo. I04, I64 S.W. 2d 92 I (1942); Aetna Ins. Co. v. O'Malley, 342 Mo. 800 , II 8 S.W. 2 d 3 (1938).

Officially, the term rule is in force in Pennsylvania, but the cases present all sorts of "exceptions"-default judgments, judgments by confession, judgments obtained through fraud or misrepresentation. See Clendenning v. Pearson, 62 D. \& C. I42 (Pa., I947); Dellacasse v. Floyd, 332 Pa. 218, 2 A. 2d 860 (I938); Dormont Motors, Inc. v. Hoerr, I32 Pa. Super. 567, I A. $2 \mathrm{~d} 493$ (r938) ("circumstances that presented a strong reason for equitable relief"); Cesare v. Caputo, I0o Pa. Super. I88 (I930); Hambleton v. Yocum, I08 Pa. 304 (I885); O'Donnell v. Flanigan, 9 Pa. Super. I36, I39 (I898) ("extraordinary cause"); Mather's Executor v. Patterson, 33 Pa. 485, 487 (I859); Stephens v. Cowan, 6 Watts (Pa.) 5 II, $5 I_{3}$ ( 1837 ). A Pennsylvania jurist of a century ago said: "I cannot help thinking that the assertion, so often made, that no Court can reverse or amend its own final judgments for errors of fact or law, after the term at which they were entered is, so far as our practice is concerned, little else than a humbug, useful only to frighten ignorance and rashness from meddling with matters too great for their comprehension. . . . It was applied in England to prevent alteration of the records after enrollment. But here they are never enrolled... . The fact is, we amend, open, and set aside judgments not only after a term, but after years, governed only by the facts and equity of the case." Lowrie, J., in Stephens v. Stephens, I Phila. Rep. (Pa.) 108, rog (r850).

In West Virginia, the term rule is applied rather strictly, although there are admittedly "exceptions." Baker v. Gaskins, x28 W.Va. 427, 36 S.E. $2 d 893$ (I946); see State v. De Berry, r3o W.Va. 4I8, 43 S.E. 2d 408 (1947); Chaney v. State Compensation Comm'r, I27 W.Va. 52I, 33 S.E. 2d 284 (1945); Helms v. Greenbriar Valley Cold Storage Co., 65 W.Va. 203, 63 S.E. I089 (Igog); Barbour County Court v. O'Neal, 42 W.Va. 295, 26 S.E. 182 (1896).

19 New England Furniture \& Carpet Co. v. Willcuts, 55 F. 2d 983 (Minn., I93 ); United States v. Mayer, 235 U.S. 55 (rgI4); Ex parte Sibbald v. United States, I2 Pet. (U.S.) 488 (I838); Cameron v. McRoberts, 3 Wheat. (U.S.) 59I (I8I8); Hudson \& Smith v. Guestier, 7 Cranch (U.S.) I (I8r2); Moore \& Rogers, Federal Relief from Civil Judgments, 55 Yale L. J. 623,627 (1946). Only the old writs of coram nobis, coram vobis and audita querela at law, and bill of review and bill in the nature of a bill of review at equity, might be brought to upset a judgment even after the expiration of the term. New England Furniture \& Carpet Co. v. Willcuts, supra; United States v. Mayer, supra; Ex parte Sibbald v. United States, supra; Moore \& Rogers, op. cit. supra. Audita querela: Humphreys v. Leggett, 9 How. (U.S.) 296, 3 I2 (I850); 3 Moore, Federal Practice $\$ 60.03$ (I938). Judgments which a court considered void could be set aside at any time. United States v. Sotis, 13 I F. 2d 783 (C.A. 7th, I942); see Phelan v. Bradbury Bldg. Corp. 7 F.R.D. 429 (N.Y., 1947); Simonds v. Norwich Union Indemnity Co., 73 F. 2d 4I 2, 4I 5 (C.A. 8th, 1934). This last was hardly an exception, since such a judgment was considered a nullity; it "never had existed." 
period was never to exceed six months. ${ }^{20}$ Experience demonstrated however that the rule suffered in some respects from poor draftsmanship. These defects were cured by judicial implementation. ${ }^{22}$ Substantial changes were made in

${ }^{20}$ Young v. Garrett, ${ }_{59}$ F. 2d 634 (C.A. 8th, x947); Wallace v. United States, r $42_{2}$ F. 2d 240 (C.A. 2d, x944); Cassell v. Barnes, x F.R.D. Is (D.C., 1939).

The ancestor of the present rule in federal courts covering the subject of relief from judgments, contained in the first draft of the Advisory Committee on the Rules of Civil Procedure, was timid and nonrevolutionary. Preliminary Draft of Rules of Civil Procedure for the District Courts of the United States, May, I936, Rule 66(b), at II5; see Report of the Advisory Committee on Rules for Civil Procedure containing Proposed Rules of Civil Procedure for the District Courts of the United States, April x937, Rule 57(b), at $x_{43}$. It provided for relief from judgments on the grounds of "accident, mistake, surprise or inadvertence; fraud, misrepresentation, or other misconduct of an adverse party; material evidence newly discovered." The grounds for relief provided were far more liberal than most state statutes. When it came to imposing a time limit however, this early provision was amazingly niggardly. Relief was to be granted "[o]n motion duly made ... before the time for appeal has expired." The rule ended with a clause saving to the court its power to "entertain an independent action to relieve a party or his legal representative from a judgment. ..." This clause was felt by the Committee to retain "what was formerly known as a bill of review." This clause was retained in the rule as adopted, and was later interpreted by the courts to preserve the whole battery of ancient remedies. Coram nobis: McGinn v. United States, 2 F.R.D. 562 (Mass., I942); Preveden v. Hahn, 36 F. Supp. $95^{2}$ (N.Y., x94I). Coram vobis: McGinn v. United States, supra; Cavallo v. Agwilines, 2 F.R.D. 526 (N.Y., 1942); Preveden v. Hahn, supra. Audita querela: Oliver v. City of Shattuck, I57 F. 2d I5० (C.A. roth, I946); see Assmann v. Fleming, I59 F. 2d 332, 335 (C.A. 8th, 1947). Bill of review: United States v. Certain Lands in Town of Highlands, 82 F. Supp. 432 (N.Y., I946); Norris v. Camp, I44 F. 2d I, 4 (C.A. Ioth, I944); Safeway Stores v. Coe, 136 F. 2d 77I (App. D.C., I943); Fraser v. Doing, r3o F. 2d 6r7 (App. D.C., r942); Preveden v. Hahn, 36 F. Supp. 952 (N.Y., I94I); Central Hanover Bank \& Trust Co. v. Wardman Real Estate Properties, Inc., 3 I F. Supp. 685 (D.C., 1940); see International Ry. Co. v. Davidson, 65 F. Supp. 58,60 (N.Y., I945); I. \& I. Holding Corp. v. Greenberg, 15I F. 2d 570, 572 (C.A. 2d, 1945).

By Federal Rule of Civil Procedure 6(c), the term rule was specifically abolished.

${ }^{21}$ Rule 60(b) spoke, for example, of "judgments, orders, and proceedings." Clearly final judgments, orders, and proceedings were meant, but the rule did not say so expressly. The word "final" was promptly inserted by the courts. See Bailey v. Proctor, I66 F. 2d 392, 395 (C.A. Ist, I948). As a result, the operation of $60(\mathrm{~b})$ in cases of bankruptcy was limited, since "no order in bankruptcy is final (in the sense that it cannot be reopened) until the proceeding has been terminated." Indemnity Ins. Co. of North America v. Reiley, I53 F. 2d 296, 298 (C.A. 2d, I945); see Grand Union Equipment Co. v. Lippner, I67 F. 2d 958, 96I (C.A. 2d, 1948) where it is said of 60 (b) that "its scope in bankruptcy is at most limited. For it is now settled that it is applicable only to final orders."

Similarly, Rule $6 \circ$ (b) did not mention fraud as a ground for the vacation of judgments. In Fiske v. Buder, 125 F. 2d 84I (C.A. 8th, 1942) this omission was "filled in" by the court, at least insofar as "extrinsic fraud" was concerned.

Under Rule 6o(b) it was further decided that error of the court, and most emphatically error of law on the part of the court, was not grounds for the vacation of a judgment. Hill $\mathrm{v}$. Hawes, 132 F. 2d 569 (App. D.C., I942) (error of the court); Jusino v. Morales \& Tio, I39 F. 2d 946 (C.A. Ist, 1944) (error of law); In re Barnett, r24 F. 2d roo5 (C.A. 2d, 1942) (error of law); Fleming v. Miller, 47 F. Supp. I004 (Minn., I942) (error of law); Nachod v. Automatic Signal Corp., $3^{2}$ F. Supp. 588 (Conn., 1940) (error of law). Nor could Rule 60(b) be invoked where the district court decision had been affirmed by a higher court. Maddrix v. Dize, 6I F. Supp. 946 (Md., I945); Albion-Idaho Land Co. v. Adams, 58 F. Supp. 579 (Idaho, I945); Home Indemnity Co. v. O'Brien, II 2 F. 2 d 387 (C.A. 6th, I940). In Miller v. United States, II4 F. 2d 267, 269 (C.A. 7 th, I940), it is said that "the District Court has no authority to to vacate a judgment by it entered in an action at law, after an appeal from said judgment has been taken." 
Rule 6o(b), however, by the amendments to the Federal Rules adopted in I948.22 These changes incorporated the experiences of the courts with Rule 6o(b) in a clear and workmanlike manner. The time limitation was extended; the situations under which relief would be given were clarified and expanded; the overlapping and obsolete writs not subject to the general rule were eliminated. Furthermore, a fundamental change in the underlying theory was incorporated. The term rule had been based on the idea that judgments should become irrevocable in a short time. The salutary changes incorporated in the original formulation of Rule 6o(b), in the suggested amendments thereto, and in the various state statutes, accept this underlying notion without question. But the new rule embodies a dramatic change, a departure from previous theory, specifically rejecting the applicability of the fixed time limit concept to certain categories.

In amended Rule 6o(b), as finally adopted, the last three clauses are not subject to the general one-year time limitation; but it is only in the last clause, clause 6 , that the departure from the fixed time limit concept is readily apparent. Clause 4 involves the situation where the "judgment is void." By definition, a motion to vacate such a judgment can be subject to no time limit. Clause 5 tells us that a judgment may be vacated when it has been "satisfied, released, or discharged, or a prior judgment upon which it is based has been reversed or otherwise vacated, ${ }^{23}$ or it is no longer equitable that the judgment should have prospective application." The second phrase refers to a type of relief formerly available under the writ of audita querela, ${ }^{24}$ and hence was always an exception to the term rule. The language is rather broad and probably will be spelled out only by a long process of judicial trial and error. Clause 6 is the broadest of all: "any other reason justifying relief from the operation of the judgment." 25 Coming at the end of a broad enumeration of grounds for the vacation of judgments, the first three clauses of which are subject to a one-year time limitation, the presence of a catch-all clause, subject to no time limitation might lead us to infer that in the federal courts judgments are never final at all.

The cases which invoke $60(\mathrm{~b})$ as amended are as yet few. By far the most

22 The old categories (mistake, inadvertence, surprise or excusable neglect) were left intact. The writs of coram nobis, coram vobis, audita querela, bills of review, and bills in the nature of bills of review were specifically abolished, however, and the type of remedy afforded by those writs was incorporated into the new rule. Second Preliminary Draft of Proposed Amendments to Rules of Civil Procedure for the District Courts of the United States, May I 945 , at $69-73$. Thus, clause 2 of amended Rule 6o(b) speaks of "newly discovered evidence," which was formerly a basis for obtaining a bill of review. Similarly, clause 3 treats of "fraud ... misrepresentation, or other misconduct of an adverse party," replacing the writ of audita querela. The distinction between intrinsic and extrinsic fraud was abolished. The time limitation was increased to one year, and made applicable to all the above cases.

23 Block v. Thousandfriend, 170 F. $2 d 428$ (C.A. 2d, 1948).

${ }_{24}$ Moore, Federal Rules and Official Forms II77 (1949).

${ }_{25}$ Moore, op. cit. supra note 24 , calls it a "statement of residual power in the court." His opinion is that since the "intendment of Rule $6 \circ(\mathrm{b})$ is that the rule be inclusive, some statement of residual power is necessary." 
important case decided under it is Klapprott $v$. United States, ${ }^{26}$ which presents the strongest indications yet available for the direction federal courts will take in the future.

August N. Klapprott was a German-American citizen, naturalized in I933 in New Jersey. On May I5, I942 the United States filed suit in the District Court of New Jersey to set aside the certificate of naturalization, on the grounds that Klapprott, a German sympathizer, had perjured himself. Klapprott was served with notice but did not answer. In July I942 judgment by default was entered by the district court. Klapprott had been arrested ten days previously on criminal charges of conspiracy to violate the Selective Service Act. He was convicted on these charges and sent to prison. In 1945 the Supreme Court reversed his conviction. In 1946 he was taken from prison to Ellis Island to be deported. On December I2, I946, Klapprott filed a petition through his attorney in the New Jersey district court asking that the default judgment be vacated and that he be granted a trial on the merits. The district court dismissed Klapprott's motion, chiefly on the grounds that the petitioner was barred by his laches. ${ }^{27}$ The circuit court affirmed this decision. ${ }^{28}$ The Supreme Court reversed the two lower court decisions by a 5-4 margin, set aside the judgment, and granted Klapprott a hearing on the merits. The decision was later modified to allow Klapprott merely to offer proof of the allegations in his complaint. Seven and one-half years had gone by since Klapprott had been denaturalized.

It is obvious from a reading of the case that the court was moved by the plight of the denaturalized citizen. But the legal basis assigned for the decision is to be found in amended Rule $6 \circ(\mathrm{b})$, which had gone into effect between the date of the circuit court decision and the Supreme Court reversal.

The "majority" that a default judgment in denaturalization cases unsupported by proof was void, and hence could be set aside at any time under clause 4 of $60(\mathrm{~b})$. But even if this were not so, he continues, the facts of the case were enough to bring it under the catch-all phrase in clause 6. Anticipating the argument of Reed's

${ }^{26} 335$ U.S. 6or (r949), modified 336 U.S. 942 (r949).

27 United States v. Klapprott, 6 F.R.D. $45^{\circ}$ (N.J., I947).

${ }^{28}$ Klapprott v. United States, I66 F. 2 d 273 (C.A. 3 d, I948).

29 Joined in only by Justice Douglas. Justice Rutledge wrote a special concurring opinion in which Justice Murphy joined, basing his decision on the position that a default judgment in a denaturalization proceeding is invalid, and that the Rules of Civil Procedure do not apply to such proceedings. He states, however, that "upon the assumption that rules of civil procedure may apply in denaturalization proceedings, I am substantially in accord with the views expressed by Mr. Justice Black." 335 U.S. 6r9, 620 (r949). The concurrence of Justice Burton "as limited to the special facts of this case and without expressing an opinion upon any issues not before this court," ibid., at $6 \times 6$, rounded out the bare majority. However, Justice Frankfurter's dissent agreed with the majority except that he was in favor of requiring Klapprott to prove his allegations before the judgment could be vacated. This is substantially the position taken by the majority of the court in the modified judgment, 336 U.S. 6or (I949). 
dissent, that all Klapprott complained of was a judgment taken because of his "excusable neglect," which would come within the one-year time limitation applied to clause $x$, Black paints a touching picture: "[I]n jail ... weakened from illness, without a lawyer in the denaturalization proceedings or funds to hire one, disturbed and fully occupied in efforts to protect himself against the gravest criminal charges, he was no more able to defend himself in the New Jersey court than he would have been had he never received notice of the charges." Black's conclusion is that the petition of Klapprott does not pray for relief merely on the grounds of "excusable neglect." "Something more" had been alleged, for which the "other reasons" clause would grant relief. Black denied that the force of that clause was limited to circumstances under which the old writs of coram nobis and audita querela would lie. "In simple English," he stated, "the language of the 'other reasons' clause, for all reasons except the five particularly specified, vests power in courts adequate to enable them to vacate judgments whenever such action is appropriate to accomplish justice." 30

The Klapprott case makes clear one thing: that portions of new Rule $6 \circ(\mathrm{b})$ give the federal courts a powerful weapon with which to upset judgments if they but choose to use it. Rule 6o(b) was thus taken by the Court to represent a complete departure from the underlying philosophy of the term rule, and to substitute a new philosophy of judgments. What are the implications of this change?

The fixed time limit concept lying behind the term rule and the statutes modifying it was bolstered up by two justifying theories. One theory was that courts could not upset their judgments because property rights had vested under them, and these property rights were not to be upset. The courts repeated this so often that they became confused, and considerations of property rights involved were transformed into the proposition that judgments were themselves property, and that to upset a final judgment was to deprive someone of property by that very act. ${ }^{35}$ Another idea that obsessed the courts was that

${ }^{30} 335$ U.S. 6or, 6r4 (r949).

${ }^{3 x}$ An extreme example is La. Civ. Code Ann. (Dart, 1942) art. 548: "A judgment, when once rendered, becomes the property of him in whose favor it has been given; and the judge cannot alter the same, except in the mode provided by law." In Wieland v. Shillock, 24 Minn. 345 ( 1877 ), a statute which provided for the vacation of judgments on the grounds of fraud was held unconstitutional insofar as it applied to judgments already rendered. "At the time of the passage of the act," said the court, "the defendant's judgment had ... become absolute, and not subject to be set aside, reversed or modified. He had, therefore, a fixed and vested right of property in it." Ibid., at 349 . The act would "deprive the defendant of his property in the judgment without due process of law."

In Johnson v. Jefferson, I9x Minn. 631,255 N.W. 87 (I934), the court held that, in a claim arising under the workmen's compensation act, where compensation was declared at an end and the rights of the parties were finally determined and fixed, and an act was subsequently passed giving the commission which had adjudicated the claim the right to "set aside its decision ... and grant a new hearing," the relators "had a fixed and vested right in the final determination made by the commission." Ibid., at $6_{33}$ and 88. Again, the act was held repugnant to the Fourteenth Amendment.

Note the language of the United States Supreme Court in McCulloch v. Virginia, I72 U.S. 
after the end of the term they lost jurisdiction over the case. ${ }^{32}$ If they had no jurisdiction, of course, it was wrongful to hear the case.

These ideas were more often thought than expressed, and more often expressed than understood. As a result, these two theories, the "property" and the "jurisdiction" theory, are jumbled together without any attempt at separation and analysis. The situation would occasionally come up that both parties would desire to set aside a judgment after term time. If the term rule is to be based on a jurisdictional rationale, one might expect that the judgment would not be vacated in such a situation because "consent cannot confer jurisdiction." ${ }^{33}$ Many courts have behaved this way. On the other hand, if the controlling theory is a property theory, then the judgment may be set aside, because there is nothing to prevent a property owner from giving up his property if he so desires. Many courts have behaved this way also. 34

The fact that courts have failed to analyze their actions has also resulted in a

I02, I23-24 (I898): "It is not within the power of a legislature to take away rights which have been once vested by a judgment. Legislation may act on subsequent proceedings, may abate actions pending, but when these actions have passed into judgment the power of the legislature to disturb the rights created thereby ceases." Note the emphasis on the magic effect of the pronouncentent of the judgment by the court, the oracle of the law. Pending actions may be disturbed by the legislature, but once these actions have passed into the magical domain of judgment, they cannot be disturbed because some sort of "title" has "vested" in them.

Of course, the crude property notions underlying many of the decisions in the field of judgments are rarely made so explicit as in the above cases.

${ }^{32}$ Barnes v. Smith, 104 Mass. 363 ( 1870 ), is typical. Here the court says: "The petitioners have had a day in court, and the judgment of the court is final. It has passed beyond its control to alter or amend." Ibid., at 364 . Hundreds of other cases in the field echo this sort of language. See Moore \& Rogers, Federal Relief from Civil Judgments, 55 Yale L. J. 623, 629 (1946).

${ }_{33}$ Mayor of Little Rock v. Bullock, 6 Ark. (x Eng.) 282, 283 (I845), where the court said that "after the term ... the cause was no longer under the jurisdiction or control of the court, or the parties. ... [C]onsent cannot confer jurisdiction."; Anderson v. Thompson, 75 Tenn. (7 Lea) 259 (188r); Moody \& Co. v. Freeman, 24 Okla. 70r, ro4 Pac. 30 (rgog); Western Land \& Irrigation Co. v. Humfeld, rr8 Ore. 4r6, 247 Pac. I43 (I926).

34 Humphreyville v. Culver, 73 Ill. 485 (1874); Gage v. City of Chicago, r4I Ill. 642, 3 I N.E. $16_{3}$ (1892); National Home for Disabled Volunteer Soldiers v. Overholser, 64 Ohio St. 5I7, 60 N.E. 628 (IgOI); Steinhagen v. Trull, 320 Ill. 382, I5I N.E. 250 (I926); Miller v. Miller, 332 Ill. $177, x_{3}$ N.E. 343 ( $x_{928}$ ), a suit for partition, where the court made much of the fact that the two parties were the "only persons who had an interest in the real estate sought to be partitioned." Ibid., at 180 and 344 ; Slattery v. Uvalde Rock Asphalt Co., I4O S.W. 2d 987, 992 (Tex. Civ. App., I940); Reisman v. Central Mfg. Dist. Bank, 316 Il. App. 37 I, 45 N.E. 2d 90 (I942).

Strangely enough, the most sensible solution was proposed in one of the oldest cases, Kidd v. McMillan, 2I Ala. 325, 327 (I852), where the court said: "[T]he question before us is, whether the court is bound by law, even when the parties consent, to set aside a final judgment, at a term subsequent to its rendition and try the case again. We think not. There must be a time when litigation must end. ... If the court was bound to retry the cause again at the request of the parties... the courts would be compelled ... to retry cases, to suit the caprice or whims of the parties. This ... the courts are not bound to do. True, if it is done, we will not hold that the court acted without authority or jurisdiction. But we think the court may refuse to retry the cause without violating any principle of law." Compare this common-sense attitude with the spirit of the provisions of amended Rule $60(\mathrm{~b})$. 
failure to realize that the two rationales upon which their action might be based are both fallacious. The "term rule" is not a rule which results from the jurisdiction of courts. It is a rule which defines jurisdiction. Similarly the "property" theory is fallacious. The judgment creditor owes his claim to property of the judgment debtor to the operation of the law. His claim is enforced by a court only because his claim is righteous and pure. If proof is offered that his claim is not righteous, the court certainly ought to be able to take it away from him. There is no magic spell in the entry of a judgment. Besides, there are obviously many types of cases which this rationale would not fit at all. The Klapprott case is an outstanding example.

Clause 6 of Rule 6o(b) simply rejects these two modes of reasoning. The fear that judgments will be unstable under clause 6 is unfounded, although, once again, the effective import of the clause will depend on the course the courts will take. Obviously the clause will be invoked by attorneys with increasing frequency, especially when the one-year time limit has run against their clients. Already a large number of cases involving aliens are being pushed in the courts, ${ }^{35}$ as lawyers take the most obvious cue from the Klapprott decision. The implications of the case go far beyond the narrow fact situation.

Courts will be inclined to be receptive, however, to cases invoking clause 6 only in extraordinary situations where the equities and public policy are strongly in favor of the vacation of the judgment. Such a case is presented by the Klapprott situation. Underlying the decision is a marked disinclination to allow denaturalization without a trial on the merits. It is crucial that in the case no "property rights" were vested by the original judgment. No injustice was done to the federal government by giving Klapprott an opportunity to prove that the judgment should be vacated. It is most dubious whether a several year old judgment in a contract or tort case would be vacated by a federal court. The motion must be made, according to Rule $60(\mathrm{~b})$, whatever the grounds, within a "reasonable" time. The reason must "justify relief from the operation of the judgment." As time passes after the entering of a judgment, fewer and fewer reasons are likely to persuade a court that it would be just to grant relief from the operation of the judgment.

The history of finality of judgments in federal courts seems thus to indicate a trend away from an absolute time limit after which the judgment becomes untouchable. Crude "property" and "jurisdiction" labels have been replaced by a more flexible standard. The law seems to be evolving a doctrine whereby judgments gradually become more final as time passes. Arguments in terrorem warning of the instability of court judgments are not founded on fact. Rule 60 (b) and the Klapprott case are thus seen to be eminently realistic, despite the fact that clause 6 may be loosely drafted. Ultimately the success of the new

3s United States v. Eichenlaub, r8o F. 2d 314 (C.A. 2d, r950); United States v. Backofen, I76 F. $2 d 263$ (C.A. 3d, I949), a case involving five denaturalized aliens. 
philosophy of judgments rests in the sound discretion and good sense of the judiciary. But then, so did the old philosophy, which was found wanting.

The good sense of this approach to the problem of finality of judgments is by no means new. Almost a century ago, Lord Campbell, setting aside a judgment long after the expiration of the term, ${ }^{36}$ said: "It is suggested that such a jurisdiction as this will be liable to abuse; but I do not feel that to be a forcible argument, as the discretion of the Court is a sufficient guarantee against abuse.... We are asked what are the limits of our jurisdiction, and whether we could do this at any time. I answer that lapse of time becomes after a season a bar, as soon as the Court in its discretion sees that it has been such as must work prejudice...." ${ }_{37}$ This philosophy is well on its way to becoming law in the federal courts.

\section{BOND PURCHASES AT DISCOUNT BY "TNSTDER" DURING INSOLVENCY}

Directors are denied a profit on corporate obligations purchased at a discount in three principal situations. Purchases during hopeless corporate insolvency are considered breaches of trust. Federal bankruptcy courts apply a similar rationale to acquisitions of debt which occur when reorganization proceedings are contemplated. Where the corporation is solvent at the time of acquisition, claims are limited to cost only on evidence of overreaching, either by purchasing in competition with the corporation or through misrepresentation or nondisclosure of material facts rendering the transaction inequitable to the seller.

Petitioners in the case under discussion ${ }^{\mathrm{x}}$ sought extensions of these rules and the hesitancy of the courts tested underlying theories. Calton Crescent's sole asset was an apartment building appraised on a I942 sale proposal at $\$ 220,000$, valued throughout the period for tax purposes at $\$ 421,630$, and sold in 1946 for $\$ 300,000$. Its liabilities included a $\$ 175,000$ first mortgage and $\$ 256,000$ in income debentures. By obtaining loans which enabled Calton Crescent to pay interest due on the first mortgage and tax liabilities (thus forestalling mortgage foreclosure and tax sales), two brothers gained positions on the directorate and later assumed management responsibilities. Throughout the following three years the corporation was unable to meet interest payments on its first mortgage. During that period close relatives of the Becker brothers (their mother

${ }^{36}$ Cannan v. Reynolds, 5 El. \& Bl. $30 \mathrm{I}$ (I855).

37 Cannan v. Reynolds, 5 El. \& BI. 3or, 306 ( 1855 ). The opinion of Crompton, J., at 307 , is also of interest. He states that "this case falls within the principle on which we act every day at chambers, where we set aside judgments, whether in term or out of term, on the ground of mistake. ... I do not think either that a judgment is final as soon as it is signed, and execution executed, or that it is precarious and may be set aside at any time. ... [T] application must be made within a reasonable time after the judgment is acted upon."

I Manufacturers Trust Co. v. Becker, 338 U.S. 304 (I949), aff'g. sub nom. In re Calton Crescent, Inc., I73 F. 2d 944 (C.A. 2d, I949), aff'g. 80 F. Supp. 822 (N.X., ; I948). 